\title{
Evaluation of resistance and the role of some defense responses in wheat cultivars to Fusarium head blight
}

\author{
Nima Khaledi*, Parissa Taheri, Mahrokh Falahati-Rastegar \\ Department of Crop Protection, Faculty of Agriculture, Ferdowsi University of Mashhad, P.O. Box 91775-1163, Mashhad, Iran
}

Vol. 57, No. 4: 396-408, 2017

DOI: 10.1515/jppr-2017-0054

Received: July 19, 2017

Accepted: November 16, 2017

*Corresponding address:

khaledi.nima@mail.um.ac.ir

\begin{abstract}
Fusarium graminearum and F. culmorum are the causal agents of Fusarium head blight (FHB) in cereal crops worldwide. Application of resistant cultivars is the most effective and economic method for management of $\mathrm{FHB}$ and reducing mycotoxin production in wheat. Understanding the physiological and biochemical mechanisms involved in basal resistance of wheat to FHB disease is limited. In this research, after screening resistance levels of eighteen wheat cultivars planted in Iran, Gaskozhen and Falat were identified as partially resistant and susceptible wheat cultivars against Fusarium spp., respectively. Also, we investigated the role of hydroxyl radical $\left(\mathrm{OH}^{-}\right)$, nitric oxide $(\mathrm{NO})$, callose deposition, lipid peroxidation and protein content in basal resistance of wheat to the hemi-biotrophic and necrotrophic Fusarium species causing FHB. Nitric oxide as a signaling molecule may be involved in physiological and defensive processes in plants. Our results showed that NO generation increased in seedlings and spikes of wheat cultivars after inoculation with Fusarium species. We observed earlier and stronger callose deposition at early time points after infection by Fusarium spp. isolates than in non-infected plants, which was positively related to the resistance levels in wheat cultivars. Higher levels of $\mathrm{OH}^{-}$and malondialdehyde (MDA) accumulation (as a marker of lipid peroxidation) were observed in the Falat than in the Gaskozhen cultivar, under non-infected and infected conditions. So, estimation of lipid peroxidation could be useful to evaluate cultivars' susceptibility. These findings can provide novel insights for better recognition of physiological and biochemical markers of FHB resistance, which could be used for rapid screening of resistance levels in wheat cultivars against this destructive fungal disease.
\end{abstract}

Key words: Fusarium culmorum, Fusarium graminearum, Fusarium head blight, resistance, wheat

\section{Introduction}

Wheat (Triticum aestivum L.) is one of the most important field crops and is consumed as a major dietary source worldwide. Wheat production and yield are limited by biotic and abiotic stresses (Bahieldin et al. 2005). Fusarium head blight (FHB) is an important and destructive disease of small grain cereals including wheat. It is caused by different species of Fusarium especially, F. graminearum and F. culmorum (Nielsen et al. 2011). The disease not only reduces the yield and quality, but also contaminates the product with various mycotoxins. Mycotoxins have various acute and chronic effects on human and animal health (Shin et al. 2014).

Several strategies have been used to manage FHB disease and reduce the risk of mycotoxin contamination, including crop rotation, genetic resistance, application of natural compounds, as well as chemical and biological control (Mesterházy 2014; Tian et al. 2016 ). Application of resistant cultivars, plant extracts and essential oils, such as thymol oil and Galla chinensis extract, are the most effective, economic, and environmentally safe ways to control plant diseases (Forrer 
et al. 2014; Khaledi et al. 2015; Lenc et al. 2015; Gill et al. 2016). To date, two main types of resistance to FHB are widely accepted: type I - resistance to initial infection, type II - resistance to fungal spread within the spike. Additionally, three other types of resistance were reported by Mesterházy et al. (1999): type III - resistance to deoxynivalenol (DON) accumulation, type IV - resistance to kernel infection, type $\mathrm{V}$ - tolerance. Different wheat genotypes express various levels of resistance against Fusarium spp. causing FHB (Mesterházy et al. 2005). Resistance to FHB is a complex trait, with polygenic inheritance and its expression is influenced by the environment (Liu et al. 2009; Ruan et al. 2012; Buerstmayr and Buerstmayr 2015).

After recognition of the pathogen, basal defense responses lead to activation of several resistance mechanisms such as production of reactive oxygen species (ROS) (Shetty et al. 2008; Khaledi et al. 2016), reactive nitrogen species (RNS) (Hong et al. 2008; Duan et al. 2015), deposition of callose (Ellinger et al. 2014), enzymatic and non-enzymatic antioxidants (Zhou et al. 2007; Khaledi et al. 2016). In plant-pathogen interactions, one of the earliest plant defense responses is production of ROS (Shetty et al. 2008). The most important ROS are superoxide anion $\left(\mathrm{O}_{2}^{-}\right)$, hydroxyl radical $\left(\mathrm{OH}^{-}\right)$, hydrogen peroxide $\left(\mathrm{H}_{2} \mathrm{O}_{2}\right)$, singlet oxygen $\left({ }^{1} \mathrm{O}_{2}\right)$ and the closely related RNS, nitric oxide (NO) (Shetty et al. 2008; Das and Roychoudhury 2014).

Callose deposition frequently occurs as a consequence of ROS burst (Zhang et al. 2009). Accumulation of ROS contributes to the induction of defense genes, and cell wall reinforcement by callose deposition (Yi et al. 2014). Generation of ROS leads to callose deposition at sites of penetration, which is recognized as an early defense response of a host to microbial pathogens (Altinok and Dikilitas 2014).

Active reinforcement of the cell wall through deposition of cell wall appositions, known as papillae, at sites of interaction with pathogens appears to be a common component of the pathogen-associated molecular patterns (PAMP) triggered immunity response (Nicaise et al. 2009; Underwood 2012; Voigt 2014). Compounds commonly associated with papillae include: callose, phenolics including lignin and phenolic conjugates such as phenolic-polyamines, ROS, peroxidases, cell wall structural proteins such as arabinogalactan proteins and hydroxyproline-rich glycoproteins, and cell wall polymers including pectin and xyloglucans (Paris et al. 2007; Hematy et al. 2009).

Plants exhibit physiological or biochemical and structural changes in cell walls in response to biotic and abiotic stress. Mechanical wounding, physiological stress and phytopathogen infection can induce callose synthesis (Tortora et al. 2012). Callose, a linear $\beta$-1,3-glucan with some $\beta$-1,6-branches, plays important roles during a variety of processes in plant development and in response to multiple biotic and abiotic stresses (Chen and Kim 2009). Callose deposition is typically triggered by conserved PAMPs (Gomez-Gomez et al. 1999). Wheat cultivars, which were partially resistant to F. graminearum, showed increased callose deposition in the transition zone of the spikelet's rachilla and rachis (Ribichich et al. 2000). Callose accumulation at sites of pathogen penetration is known as a physical barrier to slow pathogen invasion (Jones and Dangl 2006).

Hydrogen peroxide can react with metal ions via the Fenton pathway to generate the extremely toxic and highly reactive $\mathrm{OH}^{-}$, which can react indiscriminately with all macromolecules such as DNA, lipids, proteins and carbohydrates (Imlay 2003). Hydroxyl radical could be involved in initiating the oxidation of polyunsaturated phospholipids, thus leading to impairment of membrane function (Schneider et al.2008; Ayala et al. 2014). Malondialdehyde (MDA) is one of the final products of lipid peroxidation, which is an indicator of oxidative damage in plant cell membranes induced by stress (Singh et al. 2012; Wang et al. 2014). It is known that besides drought, pathogenic fungi can also change the MDA content in plants (Chen et al. 2008; Noorbakhsh and Taheri 2016).

The NO, similar to ROS, is a small redox signal and ubiquitous bioactive molecule, which is known as a relatively stable radical but rapidly reacts with other radicals including ROS (Hill et al. 2010). The NO and NO-derived RNS are produced in the chloroplasts and mitochondria (Galatro et al. 2013). Nitric oxide functions as a signaling molecule and plays an important role during interaction of plant and pathogen (Guo et al. 2004; Qiao et al. 2015). This gaseous molecule is a signaling messenger involved in plant responses to different stresses (Gaupels et al. 2011). Like ROS, $\mathrm{NO}$ is an important messenger in many physiological processes and defense reactions in cooperation with ROS (Hong et al. 2008). Nitric oxide interacts with ROS and is involved in stomatal closure and pathogen defense (Mur et al. 2013). Reactive nitrogen species are important signal transduction molecules in wheat defense against biotic and abiotic stress (Guo et al. 2004; Mur et al. 2013; Duan et al. 2015; Qiao et al. 2015).

Proteins play important roles in recognition and defense against pathogens (Zhang et al. 2013b; Zhu et al. 2010). Production of the proteins which are involved in primary metabolism, oxidative stress, detoxification, and signal transduction as well as some proteins with other functions, increased in response to fungal infection (Yang et al. 2011). Zhang et al. (2013b) reported that differentially expressed proteins may be involved in complicated processes to defend against fungal infection in FHB-resistant genotypes by degrading fungal cell walls and strengthening plant cell walls. Proteomic analysis of wheat spikes in resistant 
cultivar - F. graminearum interaction revealed accumulation of plant proteins involved in oxidative stress, pathogenesis-related (PR) responses and nitrogen metabolisms (Zhou et al. 2005).

Despite the economic importance of FHB and mycotoxins in wheat, the current understanding of resistance cultivars and defense mechanisms in wheat defense against different Fusarium species causing FHB is limited. Therefore, the objectives of this study were to: i) screen and identify the sources of resistance in Iranian wheat cultivars against FHB; ii) examine the effect of Fusarium species causing FHB on defense responses of wheat by inoculating wheat spikes and leaf segments; iii) investigate changes of $\mathrm{OH}^{-}$and $\mathrm{NO}$ at two growth stages of wheat; and iv) to compare the $\mathrm{MDA}$, callose and protein contents in partially resistant and susceptible wheat cultivars as a part of defense mechanisms involved in this pathosystem.

\section{Materials and Methods}

\section{Wheat cultivars and plant growth conditions}

Fifteen spring wheat (Triticum aestivum L.) cultivars including Falat, Roshan, Sivand, Kouhdasht, Morvarid, Gonbad, Shiroodi, Tajan, Atrak, Arta, N87-20, Ofogh, Pishtaz, Sirvan, Sumai3 and three winter wheat cultivars including Gaskozhen, Zare and Mihan with different levels of FHB resistance, obtained from the Agricultural Research Center of Khorasan Razavi, Tehran, Golestan and Yazd provinces in Iran were used. These cultivars are commonly planted in Iran because of their good quality and high yield under the climatic conditions of this country. The seeds were surface sterilized with $1 \%$ sodium hypochlorite for $1 \mathrm{~min}$, rinsed three times with sterile distilled water and incubated for 5 days on wet, sterile filter paper in Petri dishes at $25^{\circ} \mathrm{C}$. Each germinated seed was sown in a $15-\mathrm{cm}$-diameter plastic pot filled with potting soil, which had been autoclaved at $121^{\circ} \mathrm{C}$ for a minimum of $30 \mathrm{~min}$ at $100 \mathrm{kPa}$ (15 psi) on 2 successive days and grown under greenhouse conditions $\left(30 \pm 4^{\circ} \mathrm{C}\right.$; $16: 8 \mathrm{~h} \mathrm{~L}: \mathrm{D}$ photoperiod). The winter wheat cultivars require vernalization to initiate flowering. These cultivars were vernalized in a germination tray for 6 weeks at $4^{\circ} \mathrm{C}$ in a growth chamber (Bernardo et al. 2007). After vernalization, the seedlings were transplanted. The soil used in this experiment, was a combination of clay, sand and farmyard manure at a ratio of $2: 1: 1(\mathrm{v} / \mathrm{v} / \mathrm{v})$.

\section{Fungal isolates and inoculum preparation}

Isolates FH1 of F. graminearum and FH9 of F. culmorum belonging to the nivalenol (NIV) chemotype obtained from symptomatic wheat plants in the Golestan province of Iran and deposited in the fungal culture collection of Ferdowsi University of Mashhad, were used to determine sources of resistance to FHB (Khaledi et al. 2017). The isolates were grown at $25^{\circ} \mathrm{C}$ with alternate cycles of $12: 12 \mathrm{~h}(\mathrm{~L}: \mathrm{D})$ on potato dextrose agar (PDA). Fungal inocula were produced on mung bean broth (MBB) and synthetic nutrient agar (SNA) media as described by Zhang et al. (2013a) and Koch et al. (2013), respectively. Conidial suspensions were diluted with autoclaved water to a final concentration of $1 \times 10^{5}$ conidia $\cdot \mathrm{ml}^{-1}$ containing $0.05 \%$ (v/v) Tween 20.

\section{Plant inoculation and disease evaluation}

In the greenhouse experiments, a pathogenicity test on wheat spikes was carried out using the method described by Yoshida et al. (2007). At the flowering stage (ZGS 64 to 65$), 10 \mathrm{ml}$ of a spore suspension $\left(1 \times 10^{5} \mathrm{co}-\right.$ nidia $\cdot \mathrm{ml}^{-1}$ ) amended with $0.05 \%$ Tween 20 was sprayed on the spikes of each plant. The inoculated plants were incubated overnight in a greenhouse at $18-25^{\circ} \mathrm{C}$, with 90-100\% humidity. Then, the plants were placed in a plastic bag for 3 days to maintain high relative humidity. Control plants were treated with sterile distilled water containing $0.05 \%(\mathrm{v} / \mathrm{v})$ Tween 20 . Inoculated wheat heads were evaluated after 10 days and the FHB disease severity was estimated. In all cases, when lesions developed, the pathogen was reisolated from infected plants. Disease severity was measured as the percentage of infected spikelet(s) within the spike using a 0 to 5 scale ( 0 - no disease, 1 - to $20 \%, 2$ - to $40 \%, 3$ - to $60 \%, 4-$ to $80 \%$ and 5 - more than $80 \%$ disease severity). Disease incidence was expressed as the percentage of spikes infected in the plot, from $0 \%$ (no infection) to $100 \%$ (indicating all spikes examined were infected). FHB index was calculated as the combination of disease severity and disease incidence (Amarasinghe et al. 2013). Each test had four replicates arranged in a randomized complete block design, and the experiment was repeated three times.

In the detached leaf bioassay, 4-cm length segments from the mid-section were prepared from the apical leaf of 4-week-old wheat plants. Each leaf segment was placed adaxial surface uppermost on the surface of $0.5 \%$ water agar as described by Browne and Cooke (2004). Leaf segments were inoculated at the center of the adaxial surface with $5 \mu \mathrm{l}$ inoculum suspension of $1 \times 10^{5}$ conidia $\cdot \mathrm{m}^{-1}$ containing $0.05 \%(\mathrm{v} / \mathrm{v})$ Tween 20. Control leaf segments were inoculated using a drop of sterile distilled water containing $0.05 \%$ Tween 20 without the fungus. Petri dishes were incubated at $25^{\circ} \mathrm{C}$ with a $12: 12 \mathrm{~h}$ (L : D) cycle. After 5 days, the length of necrotic lesions was measured. The test included four replicates for each isolate and the experiment was repeated three times. 


\section{Callose deposition assay}

Quantification of callose deposition was performed as described by Yi et al. (2014). Leaves of 4-week-old wheat plants at various time points after the pathogen inoculation were sampled and investigated for callose deposition. Briefly, leaf segments were incubated for at least $24 \mathrm{~h}$ in $95 \%$ ethanol until all tissues were transparent, then washed in $0.07 \mathrm{M}$ phosphate buffer (pH 9) for $15 \mathrm{~min}$, and incubated for $1-2 \mathrm{~h}$ in $0.07 \mathrm{M}$ phosphate buffer containing $0.01 \%$ aniline blue (Sigma) prior to microscopic analysis. Observations were performed with a fluorescence microscope (Olympus BX51) using UV filter.

In addition, the callose content was quantitatively measured by the method of Hirano et al. (2004). Twenty $\mathrm{mg}$ plant tissues were washed once with $96 \%$ ethanol and three times with $20 \%$ ethanol which contained 5\% polyvinylpolypyrrolidone (PVP, w/v). To solubilize the callose, $1 \mathrm{ml}$ of $1 \mathrm{M} \mathrm{NaOH}$ was added to the washed tissues and the tubes were heated at $80^{\circ} \mathrm{C}$ for $15 \mathrm{~min}$. The extract was then centrifuged at $10,000 \times g$ for $15 \mathrm{~min}$ and the supernatant was assayed for callose. The callose content was quantified spectrofluorometrically at excitation and emission wavelengths of 393 and $484 \mathrm{~nm}$, respectively. Curdlan ( $\beta$-1,3-glucan) was used to prepare a calibration curve. Callose content was expressed as curdlan equivalents (CE) per mg fresh leaf weight $(\mathrm{FW})\left(\mu \mathrm{g} \mathrm{CE} \cdot \mathrm{mg}^{-1} \mathrm{FW}\right)$.

\section{Quantitative measurement of $\mathrm{OH}^{-}$}

The $\mathrm{OH}^{-}$content was assayed using the method of Halliwell et al. (1987). Fresh plant tissue (50 mg) was homogenized on ice with $1 \mathrm{ml}$ of $10 \mathrm{mM}$ phosphate buffer ( $\mathrm{pH}$ 7.4) containing $15 \mathrm{mM}$ 2-deoxyderibose, at $37^{\circ} \mathrm{C}$ for $2 \mathrm{~h}$. Following incubation, an aliquot of $0.7 \mathrm{ml}$ from the above mixture was added to the reaction mixture containing $3 \mathrm{ml}$ of $0.5 \%(\mathrm{w} / \mathrm{v})$ thiobarbituric acid (TBA, 1\% stock solution made in $5 \mathrm{mM}$ $\mathrm{NaOH}$ ) and $1 \mathrm{ml}$ of glacial acetic acid. The contents of the reaction mixture were heated in a water bath for $30 \mathrm{~min}$ at $100^{\circ} \mathrm{C}$, and then cooled down to $4^{\circ} \mathrm{C}$ for $10 \mathrm{~min}$. Absorbance of the reaction mixture was measured at $532 \mathrm{~nm}$. The $\mathrm{OH}^{-}$content was calculated using the molar extinction coefficient $\left(155 \mathrm{mM}^{-1} \cdot \mathrm{cm}^{-1}\right)$, and expressed as $\mathrm{nmol} \cdot \mathrm{g}^{-1} \mathrm{FW}$.

\section{Estimation of lipid peroxidation}

A quantitative index of lipid peroxidation, MDA content, was estimated according to Hodges et al. (1999). Briefly, $1.0 \mathrm{~g}$ of leaf tissue was homogenized in $20 \mathrm{ml}$ $96 \%$ ethanol : water $(80: 20 ; \mathrm{v} / \mathrm{v})$, followed by centrifugation at $3,000 \times g$ for $10 \mathrm{~min}$. Two $0.5 \mathrm{ml}$ aliquots of the alcoholic extract were taken; one was mixed with
$0.5 \mathrm{ml}$ (i) + TBA solution containing $20 \%$ trichloroacetic acid, $0.01 \%$ butylated hydroxytoluene (BHT) and $0.65 \% \mathrm{TBA}$, and the other was mixed with (ii) - TBA solution that had the same composition as solution (i) but without TBA. The mixture was heated at $95^{\circ} \mathrm{C}$ for $25 \mathrm{~min}$, cooled and then centrifuged at $4000 \times \mathrm{g}$ for $10 \mathrm{~min}$. Absorbance was measured at 440, 532 and $600 \mathrm{~nm}$. The MDA equivalent was derived from the absorbance according to Hodges et al. (1999).

\section{Determination of endogenous NO content}

Nitric oxide content was determined according to Murphy and Noack (1994). Fresh plant tissue (3 g) was incubated with 100 units of catalase and 100 units of superoxide dismutase for $5 \mathrm{~min}$ to remove endogenous ROS before the addition of $10 \mathrm{ml}$ of oxyhemoglobin (5 mM). After 2 min of incubation, $\mathrm{NO}$ was measured spectrophotometrically based on the conversion of oxyhemoglobin to methemoglobin. Absorbance was determined at $550 \mathrm{~nm}$ and NO content was expressed as $\mu \mathrm{mol} \cdot \mathrm{ml}^{-1} \cdot \mathrm{g}^{-1} \mathrm{FW}$.

\section{Estimation of total protein}

The protein concentration was determined as described by Bradford (1976) using bovine serum albumin as a standard.

\section{Statistical analysis}

All experiments included three independent repetitions carried out with four replications in each repetition. The means were separated using Duncan's multiple range tests at $\mathrm{p}<0.05$, where the F-value was significant. Statistical analysis was performed with statistical package for the social sciences (SPSS; version 23) software.

\section{Results}

\section{Greenhouse evaluation of FHB resistance in wheat cultivars and virulence of Fusarium isolates}

The results of evaluating resistance of 18 wheat cultivars to the isolates $\mathrm{FH} 1$ of $F$. graminearum and $\mathrm{FH} 9$ of F. culmorum revealed significant differences in the resistance levels of various cultivars to the pathogens (Fig. 1, Table 1). Triticum aestivum L. cv. Gaskozhen showed the lowest disease progress with an average FHB index of $16.5 \pm 0.82$ and mean lesion length of $13 \pm 1.18$ on the leaf segments among all tested cultivars. A significant difference was not observed between the Sumai 3 and Gaskozhen cultivars. The Falat cultivar showed 
Table 1. Average of FHB index and leaf lesion length caused by Fusarium isolates on each wheat cultivar and each isolate on all cultivars

\begin{tabular}{lcc}
\hline Cultivars/Isolates & Average of FHB index & Average of leaf lesion length \\
\hline Wheat cultivars & & \\
\hline Falat & $55.5 \pm 1.19 \mathrm{a}$ & $35.3 \pm 2.13 \mathrm{a}$ \\
Pishtaz & $42.5 \pm 1.37 \mathrm{e}$ & $27.5 \pm 1.86 \mathrm{c}$ \\
Gaskozhen & $16.5 \pm 0.82 \mathrm{~h}$ & $13.0 \pm 1.18 \mathrm{~g}$ \\
Zare & $51.0 \pm 1.00 \mathrm{~b}$ & $29.0 \pm 2.31 \mathrm{~b}$ \\
Mihan & $29.5 \pm 1.76 \mathrm{f}$ & $23.0 \pm 2.04 \mathrm{f}$ \\
Kouhdasht & $48.0 \pm 0.95 \mathrm{c}$ & $28.5 \pm 1.06 \mathrm{c}$ \\
Morvarid & $20.5 \pm 0.90 \mathrm{~g}$ & $17.0 \pm 2.80 \mathrm{e}$ \\
Gonbad & $46.0 \pm 0.51 \mathrm{~d}$ & $28.5 \pm 4.31 \mathrm{c}$ \\
N87-20 & $47.0 \pm 0.60 \mathrm{c}$ & $29.0 \pm 0.44 \mathrm{~b}$ \\
Ofogh & $47.5 \pm 1.44 \mathrm{c}$ & $26.0 \pm 2.35 \mathrm{~d}$ \\
Sivand & $46.0 \pm 1.21 \mathrm{~cd}$ & $29.0 \pm 1.13 \mathrm{~b}$ \\
Roshan & $44.5 \pm 0.95 \mathrm{de}$ & $29.0 \pm 2.59 \mathrm{bc}$ \\
Sirvan & $51.5 \pm 0.57 \mathrm{~b}$ & $28.0 \pm 0.97 \mathrm{~b}$ \\
Arta & $43.5 \pm 0.90 \mathrm{e}$ & $29.0 \pm 1.02 \mathrm{~b}$ \\
Atrak & $41.0 \pm 1.44 \mathrm{f}$ & $30.5 \pm 1.51 \mathrm{~b}$ \\
Shiroodi & $45.0 \pm 0.68 \mathrm{~d}$ & $28.0 \pm 1.03 \mathrm{c}$ \\
Tajan & $43.0 \pm 0.71 \mathrm{e}$ & $29.5 \pm 1.03 \mathrm{~b}$ \\
Sumai3 & $17.0 \pm 0.88 \mathrm{~h}$ & $13.0 \pm 1.30 \mathrm{~g}$ \\
\hline Isolates & & $32.3 \pm 0.89 \mathrm{a}$ \\
FH1 & $33.7 \pm 0.88 \mathrm{~b}$ & $23.2 \pm 0.77 \mathrm{~b}$ \\
FH9 & $52.8 \pm 1.22 \mathrm{a}$ & \\
\hline
\end{tabular}

Averages \pm standard error (SE) are given in each column. Different letters indicate significant differences according to Duncan analysis using SPSS software $(p<0.05)$.

$\mathrm{FH} 1$ - isolate of $F$. graminearum, $\mathrm{FH} 9$ - isolate of F. culmorum

A
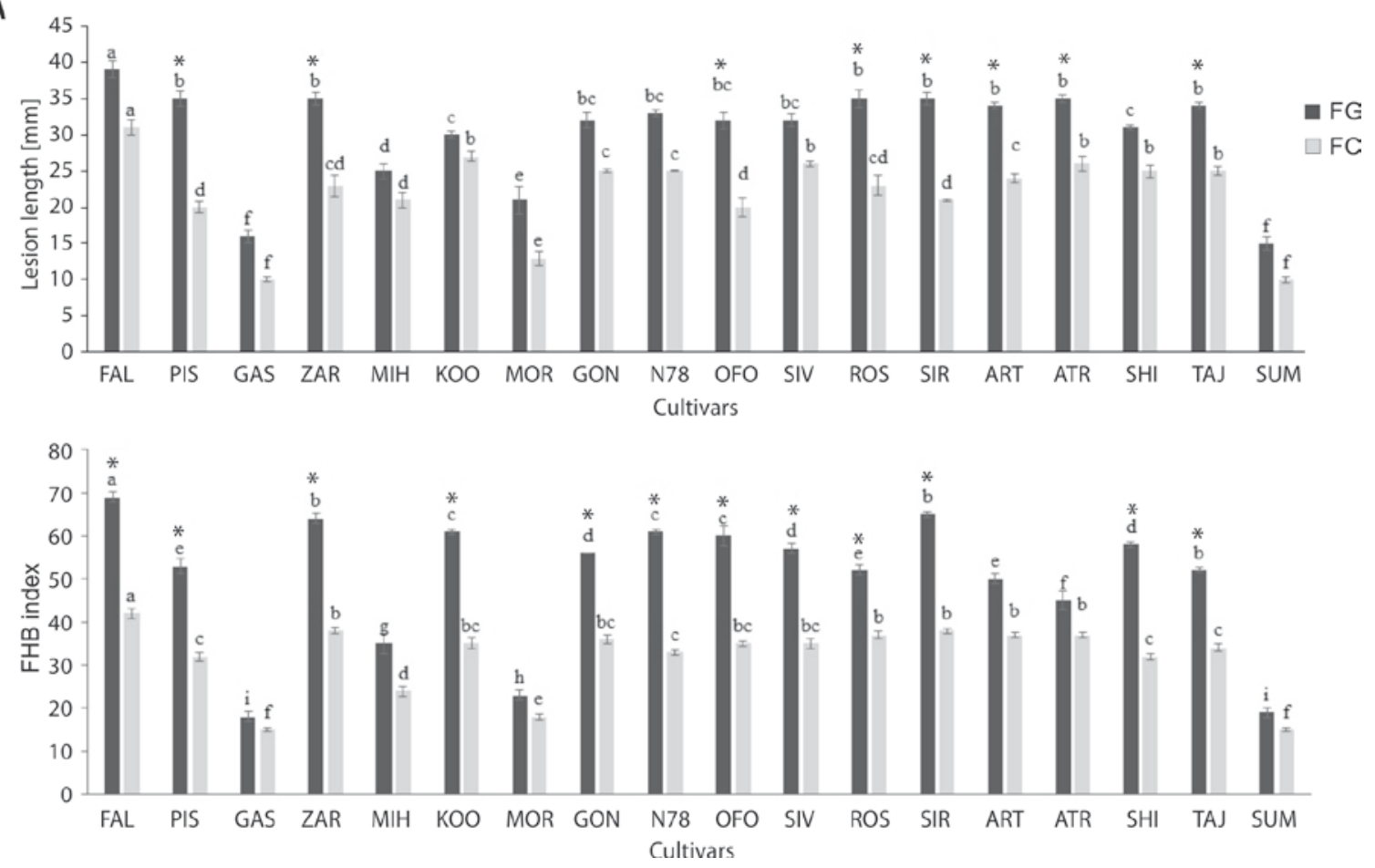

Fig . 1. Leaf lesion length (A) and FHB index (B) calculated for various cultivars of wheat (FAL - Falat, PIS - Pishtaz, GAS - Gaskozhen, ZAR - Zare, MIH - Mihan, KOO - Kouhdasht, MOR - Morvarid, GON - Gonbad, N78 - N87-20, OFO - Ofogh, SIV - Sivand, ROS - Roshan, SIR - Sirvan, ART - Arta, ATR - Atrak, SHI - Shiroodi, TAJ - Tajan, SUM - Sumai3) inoculated with isolates FH1 of F. graminearum (FG) and FH9 of F. culmorum (FC) is presented. Different letters indicate significant differences according to Duncan analysis using SPSS software $(p<0.05)$. The bars indicate standard errors (SE). Columns with an asterisk are statistically different from the control, within each treatment, according to Duncan's test $(p<0.05)$ 
the highest disease severity with an average FHB index of $55.5 \pm 1.19$ and mean lesion length of $35.3 \pm 2.13$, which was significantly higher than that of other cultivars (Table 1). Therefore, two cultivars as partially resistant (Gaskozhen) and susceptible (Falat) were used to investigate defense mechanisms. Other wheat cultivars tested fell between Gaskozhen and Falat with various levels of susceptibility to different Fusarium isolates. No complete resistance to the pathogens was observed in any of the cultivars. The Fusarium isolates used in this study revealed differences in their virulence on wheat cultivars (Fig. 1). Overall, isolate FH1 of $F$. graminearum caused the highest disease progress with an average FHB index of $52.8 \pm 1.22$ and leaf lesion length of $32.3 \pm 0.89$, which were higher than those of the FH9 isolate belonging to F. culmorum $(33.7 \pm 0.88$ and 23.2 \pm 0.77 , respectively) (Table 1).

\section{Monitoring callose deposition}

Histochemical analyses revealed higher levels of callose formation in the leaves of partially resistant Gaskozhen wheat cultivar at various time points after inoculation with isolates tested (Fig. 2A). Callose deposition was investigated in the epidermal cells of Gaskozhen and Falat leaves at various time points after inoculation with Fusarium isolates. At $24 \mathrm{hpi}$, a high level of callose deposition was observed in the leaves of Gaskozhen compared to the Falat cultivar. Callose deposition in the Falat cultivar, increased to a lesser extent and was later than in Gaskozhen plants and reached its maximum level at $48 \mathrm{hpi}$. After these time, callose deposition remained approximately the same (Fig. 2B). According to the results of determining the callose content in wheat spikes, high levels of callose deposition at milk and dough stages were observed in both cultivars (Fig. 2C). Overall, higher amount of more callose was formed in the partially resistant Gaskozhen than in the susceptible Falat cultivar. In both cultivars, a higher level of callose was detected in response to F. culmorum than to F. graminearum in both leaf and spike bioassays.

\section{Investigating $\mathrm{OH}^{-}$accumulation}

A higher level of $\mathrm{OH}^{-}$accumulation was observed in Falat than in Gaskozhen cultivar, under infected conditions. A higher level of $\mathrm{OH}^{-}$accumulation was observed in the leaves and spikes of wheat in Falat F. graminearum interaction at $120 \mathrm{hpi}$ and flowering stage, respectively (Fig. $3 \mathrm{~A}$ and $\mathrm{B}$ ).

\section{Analysis of lipid peroxidation}

We investigated lipid peroxidation, as the main destruction mechanism of oxidative stress, in the leaves and spikes of wheat cultivars inoculated with Fusarium species. In infected leaves of Falat plants, MDA contents increased until $48 \mathrm{hpi}$, as the first peak. Afterward, a decreasing rate of MDA content was observed until 72 hpi followed by the second peak at 96 hpi. In infected leaves of Gaskozhen plants, MDA contents increased until $72 \mathrm{hpi}$, and decreased afterwards (Fig. 4A). In the wheat spikes, MDA content increased after infection by Fusarium spp. isolates until milk stage, and decreased afterwards (Fig. 4B). MDA content in the leaves and spikes of wheat in Fala - F. graminearum interaction was higher than wheat cultivars - F. culmorum interaction at various time points tested.

\section{Detection of endogenous NO content}

The results revealed that endogenous NO content could be induced in wheat by Fusarium spp. infection. In infected leaves of Gaskozhen plants, NO content increased until $48 \mathrm{hpi}$, as the first peak. Afterward, a decreasing rate of NO content was observed until $72 \mathrm{hpi}$ followed by the second peak at $96 \mathrm{hpi}$. In infected leaves of Falat plants, two peaks of NO accumulation were observed at 48 and $72 \mathrm{hpi}$, with its maximum level at 48 hpi (Fig. 5A). In the wheat spikes, NO content increased after infection by Fusarium spp. isolates until milk stage, and decreased afterwards (Fig. 5B). The NO content in the leaves and spikes of wheat in Gaskozhen - F. culmorum interaction was higher than wheat cultivars - Fusarium species interaction at various time points tested (Fig. 5).

\section{Total protein content}

Total protein content was different between non-infected partially resistant and susceptible cultivars. In the Falat cultivar, a lower level of total protein was observed than in the Gaskozhen cultivar under non-infected condition. An increased protein content in the leaves and spikes of Gaskozhen cultivar infected with Fusarium spp. was observed. But in the Falat cultivar infected with F. culmorum, total protein decreased after 24 hpi (Fig. 6A). In Falat plants inoculated with F. graminearum, the levels of total protein were lower than those of non-inoculated plants of this cultivar at all time points. Higher levels of total soluble proteins were observed in the leaves of inoculated Gaskozhen plants after 48 hpi (Fig. 6A). In Gaskozhen plants, total protein of spikes slightly increased after infection by Fusarium isolates until milk stage and then decreased in consecutive growth stages, but it was still higher than that of non-infected plants. In the Falat cultivar, total protein of spikes decreased after infection by Fusarium isolates and was less than that of non-infected plants (Fig. 6B). 
A

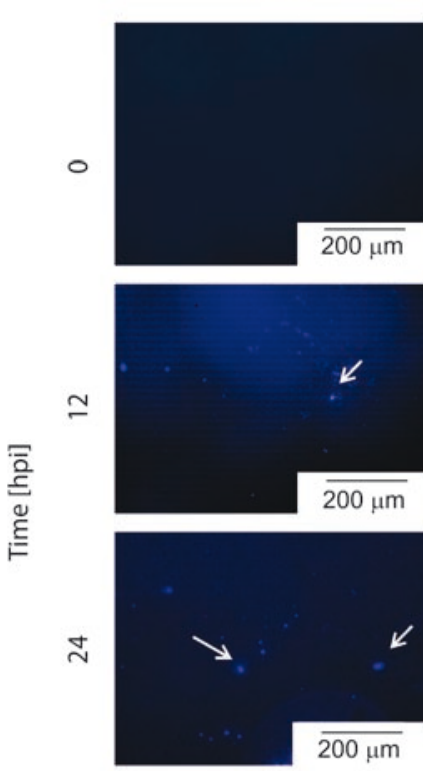

$\stackrel{\infty}{q}$

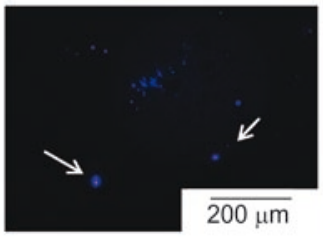

FFC
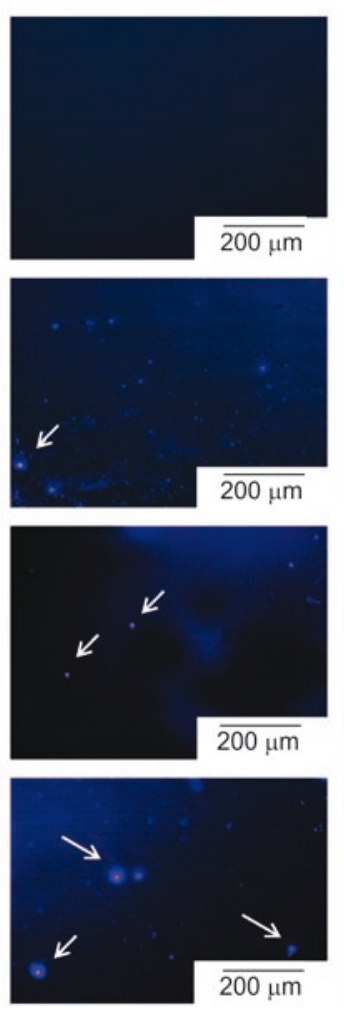

GFG
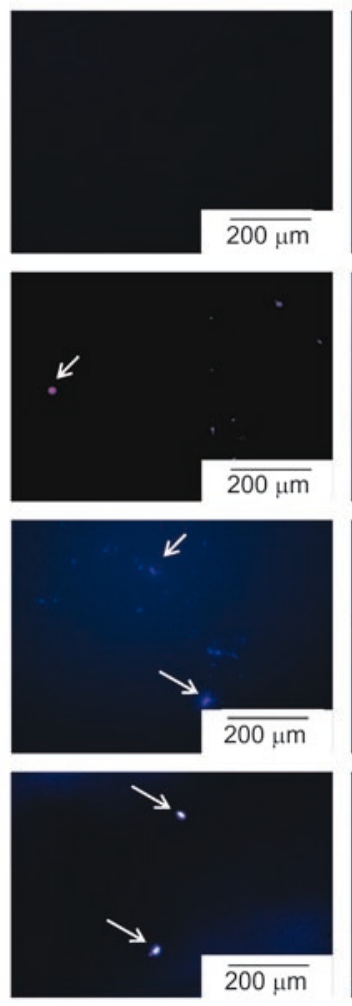

GFC
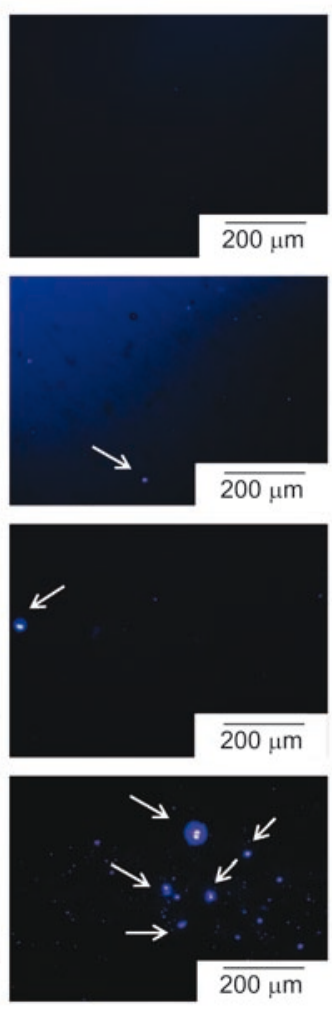

B
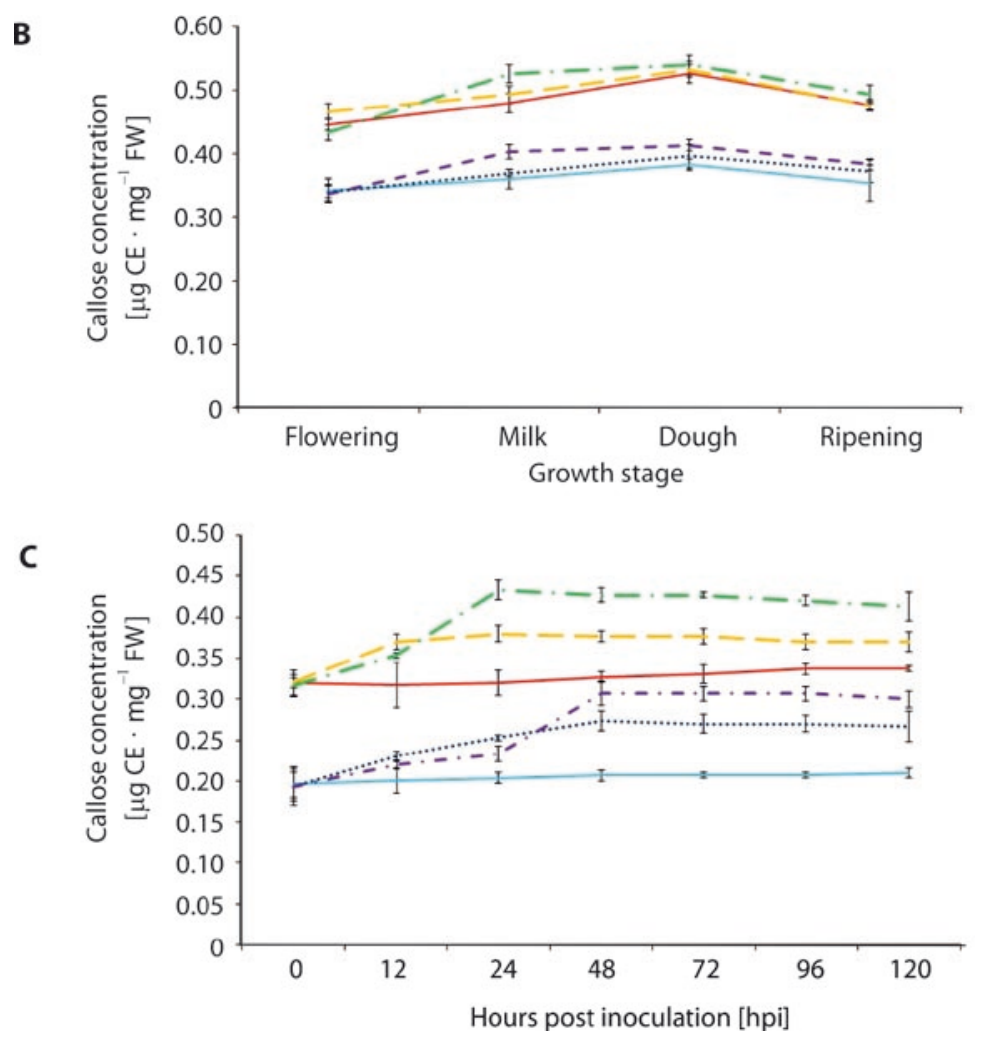

FU;

. FFG; - - - FFC; GU; - GFG; - - - GFC

FU - Falat uninoculated (control), FFG - Falat inoculated by Fusarium graminearum, FFC - Falat inoculated by F. culmorum,

GU - Gaskozhen uninoculated (control), GFG - Gaskozhen inoculated by F. graminearum, GFP - Gaskozhen inoculated by F. culmorum

Fig. 2. Callose detection in the leaves of partially resistant (Gaskozhen) and susceptible (Falat) wheat cultivars at various time points after inoculation with Fusarium spp. Distribution and amount of callose depositions stained with aniline blue until $48 \mathrm{~h}$ after pathogens challenge (arrows) (A). Callose contents were quantitatively determined in the leaves (B) and spikes (C) of wheat cultivars 
A

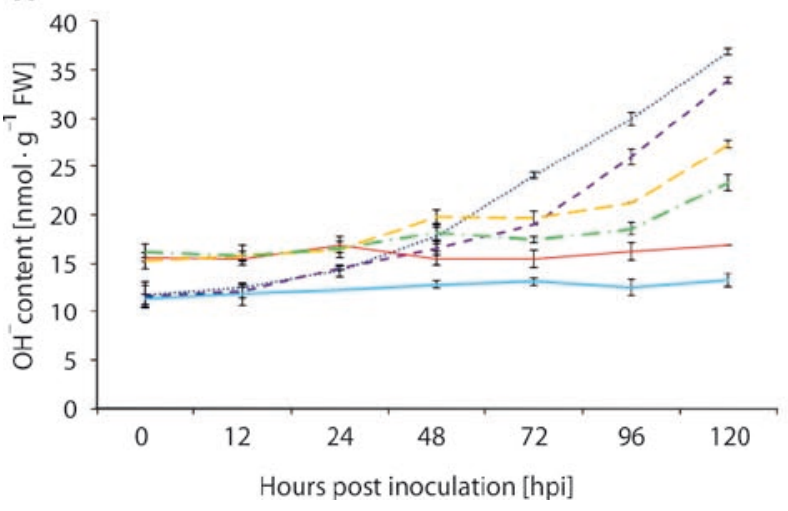

B

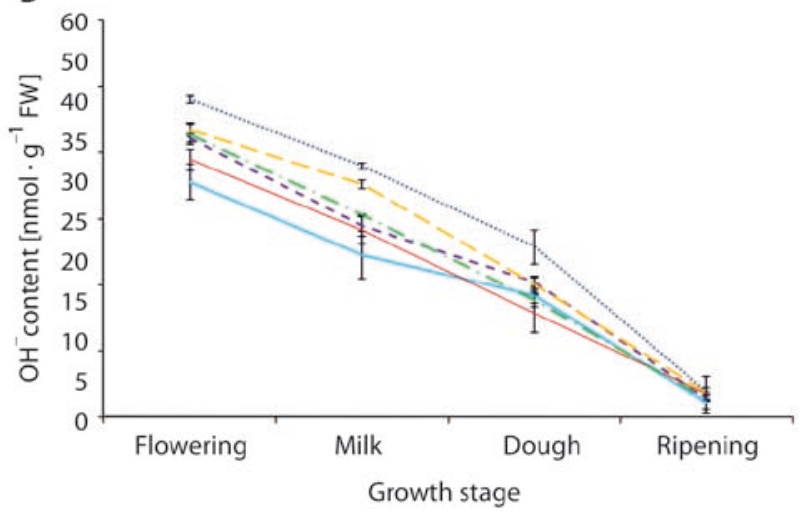

FU; - FFG; - - -FFC; - GU; - - GFG; - - - GFC

FU - Falat uninoculated (control), FFG - Falat inoculated by Fusarium graminearum, FFC - Falat inoculated by F. culmorum, GU - Gaskozhen uninoculated (control), GFG - Gaskozhen inoculated by F. graminearum, GFP - Gaskozhen inoculated by F. culmorum

Fig. 3. $\mathrm{OH}^{-}$content in the leaves (A) and spikes (B) of wheat cultivars at various time points after inoculation with Fusarium isolates

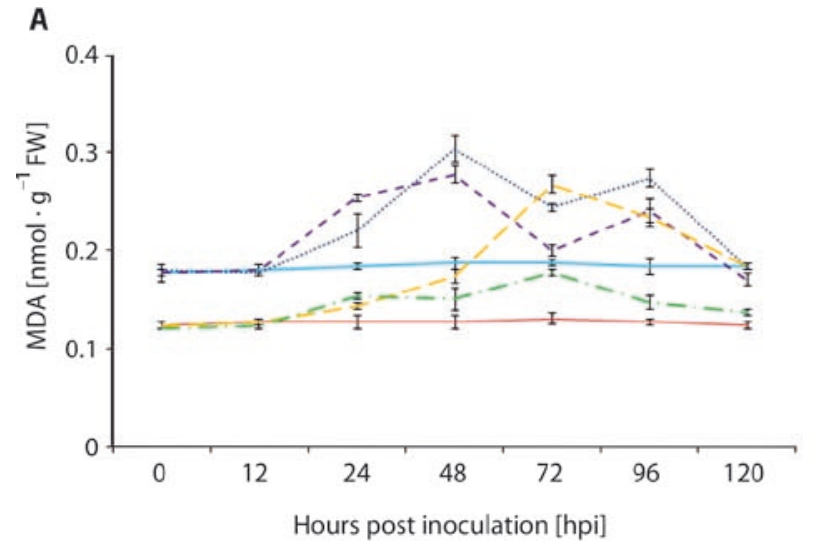

FU; FFG; - - - FFC;
B

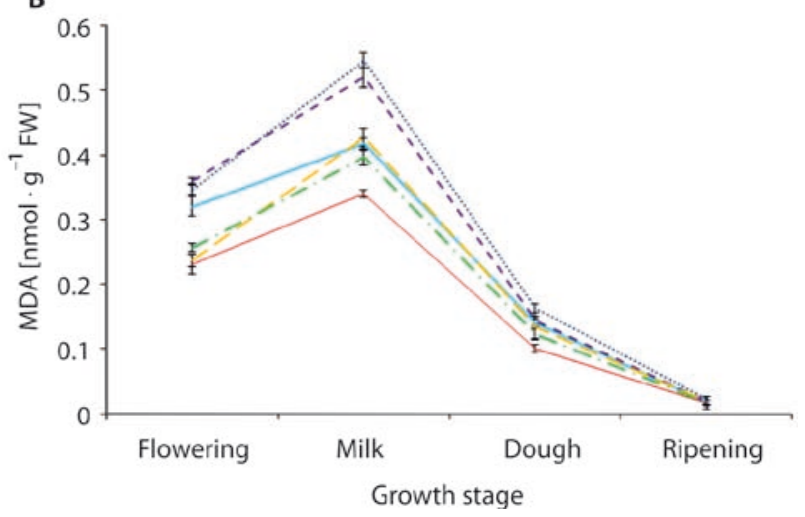

$\mathrm{GU} ;-\mathrm{GFG} ;-\cdots \mathrm{GFC}$

FU - Falat uninoculated (control), FFG - Falat inoculated by Fusarium graminearum, FFC - Falat inoculated by F. culmorum

GU - Gaskozhen uninoculated (control), GFG - Gaskozhen inoculated by F. graminearum, GFP - Gaskozhen inoculated by F. culmorum

Fig. 4. Malondialdehyde (MDA) content in the leaves (A) and spikes (B) of wheat cultivars at various time points after inoculation with Fusarium isolates

\section{Discussion}

In this study, we screened the levels of resistance to FHB disease in Iranian wheat cultivars. Also, some of the defense mechanisms involved in basal resistance of wheat cultivars to the hemi-biotrophic F. graminearum and necrotrophic F. culmorum were investigated. The obtained results provided knowledge on the physiological and biochemical aspects as a part of wheat defense against mechanisms against Fusarium spp., causing FHB, which might be used as powerful markers for determining resistant wheat cultivars to this destructive disease.

Based on the results of greenhouse infection assays, Gaskozhen and Falat plants were partially resistant and susceptible cultivars, respectively, among wheat cultivars tested.

We analyzed callose deposition, a common response by wheat to Fusarium attack, at the site of penetration. Our investigations revealed higher levels of callose deposition in Gaskozhen than in Falat cultivar. Motallebi et al. (2015) showed that callose content was higher in partially resistant wheat (Sumai3 cultivar) in response to F. culmorum than in the Falat cultivar. Also, they showed that the highest amount of callose content was seen in the Sumai3 cultivar. Similarly, Blümke et al. (2014) reported that linoleic and a-linolenic acid have a major function in the suppression of the innate immunity-related callose biosynthesis and, hence, progress of F. graminearum wheat infection. 

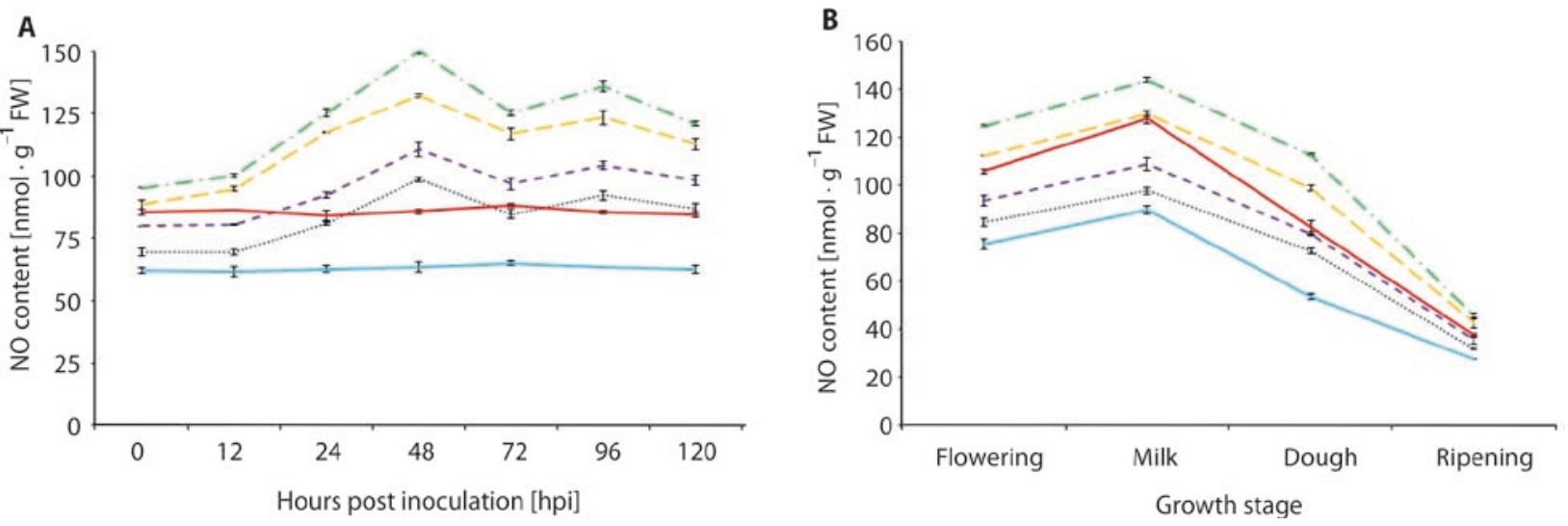

FU;

FG; $\quad--F F C$;

ธU;

- GFG; - - - GFC

FU - Falat uninoculated (control), FFG - Falat inoculated by Fusarium graminearum, FFC - Falat inoculated by F. culmorum,

GU - Gaskozhen uninoculated (control), GFG - Gaskozhen inoculated by F. graminearum, GFP - Gaskozhen inoculated by F. culmorum

Fig. 5. NO content in the leaves (A) and spikes (B) of wheat cultivars at various time points after inoculation with Fusarium isolates

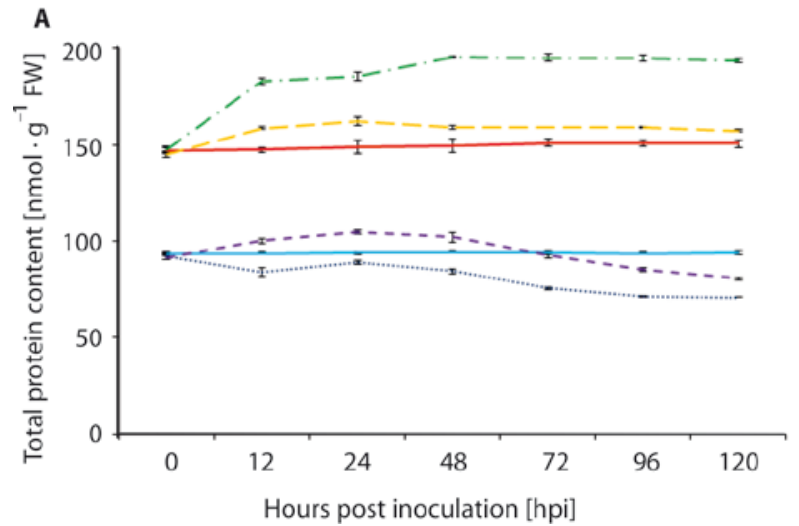

$\mathrm{FU}$;

FFG; -- FFC

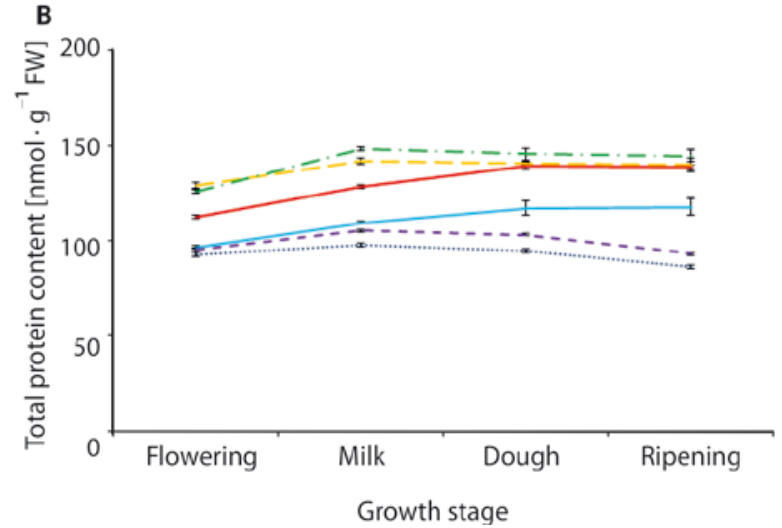

$\mathrm{GU} ;-\mathrm{GFG} ;-\cdots \mathrm{GFC}$

FU - Falat uninoculated (control), FFG - Falat inoculated by Fusarium graminearum, FFC - Falat inoculated by F. culmorum,

GU - Gaskozhen uninoculated (control), GFG - Gaskozhen inoculated by F. graminearum, GFP - Gaskozhen inoculated by F. culmorum

Fig. 6. Total protein content in the leaves (A) and spikes (B) of wheat cultivars at various time points after inoculation with Fusarium isolates

In plant-pathogen interactions, an oxidative response is an early and complex host reaction to the phytopathogens, which occur in the attacked and neighboring cells of the infection site (Dmochowska-Boguta et al. 2013; Taheri et al. 2014). We observed increased $\mathrm{OH}^{-}$content in the leaves and spikes of infected plants compared to non-infected samples. At most of the time points investigated, the $\mathrm{OH}^{-}$content in the leaves changed depending on virulence of the Fusarium isolates. It was much higher in the leaves infected with the highly virulent $F$. graminearum isolate and, conversely, decreased in the leaves infected with the hypovirulent F. culmorum isolate. Briefly, the detailed characteristics of the process may vary depending on the particular plant, pathogen and type of interaction. The $\mathrm{OH}^{-}$content increased in infected tissues compared to non-infected samples.
Considerably higher $\mathrm{OH}^{-}$content was observed in the Falat compared to the Gaskozhen cultivar. This finding is consistent with higher values of $\mathrm{OH}^{-}$scavenging activity ( $41 \%$ higher) in FHB-resistant wheat than in FHB susceptible wheat group reported by Zhou et al. (2007). Increased $\mathrm{OH}^{-}$accumulation in our assays provides support for the detrimental effect of trichothecene mycotoxins by promoting cell death through the induction of $\mathrm{H}_{2} \mathrm{O}_{2}$ and $\mathrm{OH}^{-}$production thereby disturbing the balance between production and removal of ROS in cellular components (Desmond et al. 2008; Ponts et al. 2009).

We observed a higher level of MDA accumulation in the Falat compared to the Gaskozhen cultivar, under non-infected and infected conditions. This result is in accordance with Motallebi et al. (2015), who reported higher levels of MDA in the Falat cultivar infected 
with F. culmorum compared to the partially resistant Pishtaz and Sumai3 cultivars. Sorahinobar et al. (2016) reported that seed treatment with $F$. graminearum extract significantly increased $\mathrm{H}_{2} \mathrm{O}_{2}$ and MDA contents in Sumai3 and Falat cultivars. Chakraborty and Pradhan (2012) have also reported that water stress increased accumulation of MDA in susceptible varieties compared to tolerant varieties. Tatar and Gevrek (2008) demonstrated increased MDA contents with an increasing degree of stress in wheat. Debona et al. (2012) observed increased ROS and MDA concentrations and electrolyte leakage in wheat after inoculation by Pyricularia oryzae. Also, abiotic stress such as chilling and ozone treatment increased levels of MDA and ROS (Esim et al. 2014). These findings suggest that wheat plants have similar defense strategies against various biotic and abiotic stress.

In this study, biphasic accumulation of NO was observed in partially resistant and susceptible wheat cultivars, following inoculation with Fusarium spp. isolates. Maximum rates of NO generation were observed in the leaves of Gaskozhen compared to Falat plants, under non-infected and infected conditions. However, NO contents increased in infected treatments compared to non-infected treatments. Nitric oxide generation in Gaskozhen was observed more rapidly than in the Falat cultivar. Accumulation of high NO levels in Gaskozhen at 48 hpi might be associated with a higher level of resistance in this cultivar. These results were similar to results reported by other investigators. Qiao et al. (2015) reported that NO production plays an important role in defense interactions between wheat and Puccinia triticina at 24 to 72 hpi. Guo et al. (2004) reported biphasic accumulation of NO in plant cells adjacent to the stomata and the cells surrounding an infection site of $P$. striiformis in wheat at 20 and 100 hpi, with its maximum level at $100 \mathrm{hpi}$. Also, they observed first peak of $\mathrm{NO}$ accumulation in the early infection stage whereas the second peak accumulated in the latent period. However, only a single peak of NO was observed in the latent period for the virulent isolate. RNS, such as NO and polyamines, and ROS can be directly involved in plant defense through hypersensitive response induction (Zaninotto et al. 2006). Nitric oxide acts as a signaling molecule in inducing gene expression of the enzymes such as superoxide dismutase, ascorbate peroxide and catalase (Chen et al. 2010). Wheat spikes at milk stage, showed considerably higher accumulation of NO in the Gaskozhen than in the Falat cultivar, under both non-infected and infected conditions. Our presentresultssuggested that NOmighthaveaprotective effect on wheat cultivars - Fusarium spp. interaction.

The results showed that the total protein content of Gaskozhen was higher than the Falat cultivar at various time points investigated. The present results suggested that proteins which are induced rapidly in response to pathogen invasion might help the resistant wheat cultivar to limit infection by Fusarium species. Our data are in accordance with observations of Gherbawy et al. (2012) who reported that the content of soluble, insoluble and total protein increased in wheat inoculated with Fusarium species. On the other hand, total protein decreased after the increase in infected Falat plants. This confirms the results obtained by others (Collins et al. 2003; Haynes et al. 2004; Huang et al. 2011). The Iranian wheat cultivars with different genetic backgrounds showed different levels of resistance to FHB. A difference in defense responses under FHB inoculation was observed in partially resistant (Gaskozhen) and susceptible (Falat) cultivars, which agrees with Khaledi et al. (2016).

\section{Conclusions}

According to our results, rapid induction and high amounts of NO and callose deposition, and induction of protein in resistant cultivars may play an important role in Iranian wheat cultivar resistance as mechanisms of host-resistance to FHB. We showed that there are different physiological and biochemical response patterns between Gaskozhen and Falat in response to Fusarium species infection. There were higher levels of $\mathrm{NO}$ and protein contents in Gaskozhen compared to the Falat cultivar, but accumulation of $\mathrm{OH}^{-}$and lipid peroxidation was higher in Falat than in Gaskozhen. These findings indicate the role of callose deposition, changes of protein, $\mathrm{OH}^{-}$and $\mathrm{NO}$ as defense mechanisms of wheat cultivars in interaction with Fusarium spp. The major role of NO formation in wheat resistance to FHB can be interpreted in its regulatory function on defense mechanisms. This study showed that lipid peroxidation and $\mathrm{OH}^{-}$accumulation play major roles in wheat susceptibility to FHB. Our knowledge on physiological and biochemical mechanisms involved in basal resistance could be useful in breeding programs leading to the introduction of wheat cultivars with high levels of resistance to FHB disease. Thus, the measurements of protein, $\mathrm{OH}^{-}$and $\mathrm{NO}$ levels may be very helpful for breeding programs to screen and select FHB-resistant cultivars.

\section{Acknowledgements}

We wish to thank Ferdowsi University of Mashhad, Iran, for financial support of this research with project number 31477 approved on 2/07/2014. 


\section{References}

Altinok H.H., Dikilitas M. 2014. Antioxydant response to biotic and abiotic inducers for the resistance against fusarium wilt disease in eggplant (Solanum melongena L.). Acta Botanica Croatica 73 (1): 79-92. DOI: https://doi.org/10.2478/ botcro-2013-0014

Amarasinghe C.C., Tamburic-Ilincic L., Gilbert J., Brûlé-Babel A.L., Fernando W.G.D. 2013. Evaluation of different fungicides for control of fusarium head blight in wheat inoculated with 3ADON and 15ADON chemotypes of Fusarium graminearum in Canada. Canadian Journal of Plant Pathology 35 (2): 200-208. DOI: https://doi.org/10.1080/0706066 1.2013 .773942

Ayala A., Muñoz M.F., Argüelles S. 2014. Lipid peroxidation: production, metabolism, and signaling mechanisms of malondialdehyde and 4-hydroxy-2-nonenal. Oxidative Medicine and Cellular Longevity 2014, 31 pages. DOI: https://doi.org/10.1155/2014/360438

Bahieldin A., Mahfouz H.T., Eissa H.F., Saleh O.M., Ramadan A.M., Ahmed I.A., Dyer W.E., El-Itriby H.A., Madkour M.A. 2005. Field evaluation of transgenic wheat plants stably expressing the HVA1 gene for drought tolerance. Physiologia Plantarum 123 (4): 421-427. DOI: https://doi. org/10.1111/j.1399-3054.2005.00470.x

Bernardo A., Bai G., Guo P., Xiao K., Guenzi A.C., Ayoubi P. 2007. Fusarium graminearum-induced changes in gene expression between Fusarium head blight-resistant and susceptible wheat cultivars. Functional \& Integrative Genomics 7 (1): 69-77. DOI: https://doi.org/10.1007/s10142006-0028-1

Blümke A., Falter C., Herrfurth C., Sode B., Bode R., Schäfer W., Feussner I., Voigt C.A. 2014. Secreted fungal effector lipase releases free fatty acids to inhibit innate immunityrelated callose formation during wheat head infection. Plant Physiology 165 (1): 346-358. DOI: https://doi.org/10.1104/ pp.114.236737

Bradford M. 1976. A rapid and sensitive method for the quantification of microgram quantities of protein utilizing the principle of protein dye binding. Analytical Biochemistry 72 (1-2): 248-254. DOI: https://doi.org/10.1006/ abio.1976.9999

Browne R.A., Cooke B.M. 2004. Development and evaluation of an in vitro detached leaf assay for pre-screening resistance to Fusarium head blight in wheat. European Journal of Plant Pathology 110 (1): 91-102. DOI: https://doi. org/10.1023/b:ejpp.0000010143.20226.21

Buerstmayr M., Buerstmayr H. 2015. Comparative mapping of quantitative trait loci for Fusarium head blight resistance and anther retention in the winter wheat population Capo $\times$ Arina. Theoretical and Applied Genetics 128 (8): 1519-1530. DOI: https://doi.org/10.1007/s00122-015-2527-8

Chakraborty U., Pradhan B. 2012. Oxidative stress in five wheat varieties (Triticum aestivum L.) exposed to water stress and study of their antioxidant enzyme defense system, water stress responsive metabolites and $\mathrm{H}_{2} \mathrm{O}_{2}$ accumulation. Brazilian Journal of Plant Physiology 24 (2): 117-130. DOI: https://doi.org/10.1590/s1677-04202012000200005

Chen F., Wang F., Sun H.Y., Cai Y., Mao W.H., Zhang G.P., Eva V., Wu F.B. 2010. Genotype-dependent effect of exogenous nitric oxide on Cd-induced changes in antioxidative metabolism, ultrastructure, and photosynthetic performance in barley seedlings (Hordeum vulgare). Journal of Plant Growth Regulation 29 (4): 394-408. DOI: https://doi. org/10.1007/s00344-010-9151-2

Chen X.R., Wang X.L., Zhang Z.G., Wang Y.C., Zheng X.B. 2008. Differences in the induction of the oxidative burst in compatible and incompatible interactions of soybean and Phytophthora sojae. Physiological and Molecular Plant Pathology 73 (1-3): 16-24. DOI: https://doi.org/10.1016/j. pmpp.2008.10.002
Chen X.Y., Kim J.Y. 2009. Callose synthesis in higher plants. Plant Signaling \& Behavior 4 (6): 489-492. DOI: https://doi. org/10.4161/psb.4.6.8359

Collins N.C., Thordal-Christensen H., Lipka V., Bau S., Kombrink E., Qiu J.L., Hückelhoven R., Stein M., Freialdenhoven A., Somerville S.C., Schulze-Lefert P. 2003. SNAREprotein-mediated disease resistance at the plant cell wall. Nature 425 (6961): 973-977. DOI: https://doi.org/10.1038/ nature 02076

Das K., Roychoudhury A. 2014. Reactive oxygen species (ROS) and response of antioxidants as ROS-scavengers during environmental stress in plants. Frontiers in Environmental Science 2: 53. DOI: https://doi.org/10.3389/fenvs.2014.00053

Debona D., Rodrigues F.Á., Rios J.A., Nascimento K.J.T. 2012. Biochemical changes in the leaves of wheat plants infected by Pyricularia oryzae. Phytopathology 102 (12): 1121-1129. DOI: https://doi.org/10.1094/phyto-06-12-0125-r

Desmond O.J., Manners J.M., Stephens A.E., MacLean D.J., Schenk P.M., Gardiner D.M., Munn A.L., Kazan K. 2008. The Fusarium mycotoxin deoxynivalenol elicits hydrogen peroxide production, programmed cell death and defence responses in wheat. Molecular Plant Pathology 9 (4): 435-445. DOI: https://doi.org/10.1111/j.1364-3703 .2008.00475.x

Dmochowska-Boguta M., Nadolska-Orczyk A., Orczyk W. 2013. Roles of peroxidases and NADPH oxidases in the oxidative response of wheat (Triticum aestivum) to brown rust (Puccinia triticina) infection. Plant Pathology 62 (5): 993-1002. DOI: https://doi.org/10.1111/ppa.12009

Duan X., Li X., Ding F., Zhao J., Guo A., Zhang L., Yao J., Yang Y. 2015. Interaction of nitric oxide and reactive oxygen species and associated regulation of root growth in wheat seedlings under zinc stress. Ecotoxicology and Environmental Safety 113: 95-102. DOI: https://doi.org/10.1016/j. ecoenv.2014.11.030

Ellinger D., Sode B., Falter C., Voigt C.A. 2014. Resistance of callose synthase activity to free fatty acid inhibition as an indicator of Fusarium head blight resistance in wheat. Plant Signaling \& Behavior 9 (7): e28982. DOI: https://doi. org/10.4161/psb.28982

Esim N., Atici O., Mutlu S. 2014. Effects of exogenous nitric oxide in wheat seedlings under chilling stress. Toxicology and Industrial Health 30 (3): 268-274. DOI: https://doi. org/10.1177/0748233712457444

Forrer H.R., Musa T., Schwab F., Jenny E., Bucheli T.D., Wettstein F.E., Vogelgsang S. 2014. Fusarium head blight control and prevention of mycotoxin contamination in wheat with botanicals and tannic acid. Toxins 6 (3): 830-849. DOI: https://doi.org/10.3390/toxins6030830

Galatro A., Puntarulo S., Guiamet J.J., Simontacchi M. 2013. Chloroplast functionality has a positive effect on nitric oxide level in soybean cotyledons. Plant Physiology and Biochemistry 66: 26-33. DOI: https://doi.org/10.1016/j.plaphy.2013.01.019

Gaupels F., Kuruthukulangarakoola G.T., Durner J. 2011. Upstream and downstream signals of nitric oxide in pathogen defence. Current Opinion in Plant Biology 14 (6): 707-714. DOI: https://doi.org/10.1016/j.pbi.2011.07.005

Gherbawy Y.A., El-Tayeb M.A., Maghraby T.A., Shebany Y.M., El-Deeb B.A. 2012. Response of antioxidant enzymes and some metabolic activities in wheat to Fusarium spp. infections. Acta Agronomica Hungarica 60 (4): 319-333. https:// doi.org/10.1556/aagr.60.2012.4.3

Gill T.A., Li J., Saenger M., Scofield S.R. 2016. Thymol-based submicron emulsions exhibit antifungal activity against Fusarium graminearum and inhibit Fusarium head blight (FHB) in wheat. Journal of Applied Microbiology 121 (4): 1103-1116. DOI: https://doi.org/10.1111/jam.13195

Gomez-Gomez L., Felix G., Boller T. 1999. A single locus determines sensitivity to bacterial flagellin in Arabidopsis thaliana. The Plant Journal 18 (3): 277-284. DOI: https://doi. org/10.1046/j.1365-313x.1999.00451.x 
Gündüz K., Özdemir E. 2014. The effects of genotype and growing conditions on antioxidant capacity, phenolic compounds, organic acid and individual sugars of strawberry. Food Chemistry 155: 298-303. DOI: https://doi. org/10.1016/j.foodchem.2014.01.064

Guo P., Cao Y., Li Z., Zhao B. 2004. Role of an endogenous nitric oxide burst in the resistance of wheat to stripe rust. Plant, Cell and Environment 27 (4): 473-477. DOI: https://doi. org/10.1111/j.1365-3040.2003.01165.x

Halliwell B., Gutteridge J.M.C., Auroma O. 1987. The deoxyribose method: a simple 'test tube' assay for determination of rate constants for reactions of hydroxyl radicals. Analytical Biochemistry 165 (1): 215-219. DOI: https://doi. org/10.1016/0003-2697(87)90222-3

Haynes C.M., Titus E.A., Cooper A.A. 2004. Degradation of misfolded proteins prevents ER-derived oxidative stress and cell death. Molecular Cell 15 (5): 767-776. DOI: https://doi. org/10.1016/j.molcel.2004.08.025

Hematy K., Cherk C., Somerville S. 2009. Host-pathogen warfare at the plant cell wall. Current Opinion in Plant Biology 12 (4): 406-413. DOI: https://doi.org/10.1016/j. pbi.2009.06.007

Hill B.G., Dranka B.P., Bailey S.M., Lancaster J.R.J., DarleyUsmar V.M. 2010. What part of NO don't you understand? Some answers to the cardinal questions in nitric oxide biology. The Journal of Biological Chemistry 285 (26): 19699-19704. DOI: https://doi.org/10.1074/jbc.r110.101618

Hirano Y., Pannatier E.G., Zimmermann S., Brunner I. 2004. Induction of callose in roots of Norway spruce seedlings after short-term exposure to aluminum. Tree Physiology 24 (11): 1279-1283. DOI: https://doi.org/10.1093/ treephys/24.11.1279

Hodges D.M., Delong J.M., Forney C.F., Prange R.K. 1999. Improving the thiobarbituric acid-reactive-substances assay for estimating lipid peroxidation in plant tissues containing anthocyanin and other interfering compounds. Planta 207 (4): 604-611. DOI: https://doi.org/10.1007/ s004250050524

Hong J.K., Yun B.W., Kang J.G., Raja M.U., Kwon E., Sorhagen K., Chu C., Wang Y., Loake G.J. 2008. Nitric oxide function and signaling in plant disease resistance. Journal of Experimental Botany 59 (2): 147-154. DOI: https://doi. org/10.1093/jxb/erm244

Huang M., Whang P., Chodaparambil J.V., Pollyea D.A., Kusler B., Xu L., Felsher D.W., Mitchell B.S. 2011. Reactive oxygen species regulate nucleostemin oligomerization and protein degradation. The Journal of Biological Chemistry 286 (13): 11035-11046. DOI: https://doi.org/10.1074/jbc. $\mathrm{m} 110.208470$

Imlay J.A. 2003. Pathways of oxidative damage. Annual Review of Microbiology 57 (1): 395-418. DOI: https://doi. org/10.1146/annurev.micro.57.030502.090938

Jones J.D.G., Dangl J.L. 2006. The plant immune system. Nature 444 (16): 323-329. DOI: DOI: $10.1038 /$ nature 05286

Khaledi N., Taheri P., Falahati-Rastegar M. 2016. Reactive oxygen species and antioxidant system responses in wheat cultivars during interaction with Fusarium species. Australasian Plant Pathology 45 (6): 653-670. DOI: https://doi. org/10.1007/s13313-016-0455-y

KhalediN., TaheriP., Falahati-Rastegar M. 2017. Identification, virulence factors characterization and analysis virulence together with aggressiveness of Fusarium spp., causing wheat head blight in Iran. European Journal of Plant Pathology 147 (4): 897-918. DOI: https://doi.org/10.1007/s10658-016-1059-7

Khaledi N., Taheri P., Tarighi S. 2015. Antifungal activity of various essential oils against Rhizoctonia solani and Macrophomina phaseolina as major bean pathogens. Journal of Applied Microbiology 118 (3): 704-717. DOI: https://doi. org/10.1111/jam. 12730

Koch A., Kumara N., Weberb L., Kellerc H., Imania J., Kogela K.H. 2013. Host-induced gene silencing of cytochrome P450 lanosterol C14 $\alpha$-demethylase-encoding genes confers strong resistance to Fusarium species. Proceedings of the National Academy of Sciences of the United States of America 110 (48): 19324-19329. DOI: https://doi.org/10.1073/ pnas. 1306373110

Lenc L., Czecholiński G., Wyczling D., Turów T., Kaźmierczak A. 2015. Fusarium head blight (FHB) and Fusarium spp. on grain of spring wheat cultivars grown in Poland. Journal of Plant Protection Research 55 (3): 266-277. DOI: https://doi. org/10.1515/jppr-2015-0038

Liu S., Hall M., Griffey C., McKendry A. 2009. Meta-analysis of QTL associated with Fusarium head blight resistance in wheat. Crop Science 49 (6): 1955-1968. DOI: https://doi. org/10.2135/cropsci2009.03.0115

Mesterházy Á. 2014. Chemical control of Fusarium head blight of wheat. p. 232-247. In: "Mycotoxin Reduction in Grain Chains” (J.F. Leslie, A.F. Logrieco, eds). Wiley Blackwell Ames Iowa USA. DOI: 10.1002/9781118832790.ch16

Mesterházy Á., Bartók T., Kászonyi G., Varga M., Tóth B., Varga J. 2005. Common resistance to different Fusarium spp. causing Fusarium head blight in wheat. European Journal of Plant Pathology 112 (3): 267-281. DOI: https://doi. org/10.1007/s10658-005-2853-9

Mesterházy Á., Bartók T., Mirocha C.G., Komoróczy R. 1999. Nature of wheat resistance to Fusarium head blight and the role of deoxynivalenol for breeding. Plant Breeding 118 (2): 97-110. DOI: https://doi.org/10.1046/j.1439-0523 1999.118002097.x

Montibus M., Khosravi C., Zehraoui E., Verdal-Bonnin M.N., Richard-Forget F., Barreau C. 2015. Is the Fgap1 mediated response to oxidative stress chemotype dependent in Fusarium graminearum? FEMS Microbiology Letters 363 (2): fnv232. DOI: https://doi.org/10.1093/femsle/fnv232

Moore J., Liu J.G., Zhou K., Yu L.L. 2006. Effects of genotype and environment on the antioxidant properties of hard winter wheat bran. Journal of Agricultural and Food Chemistry 54 (15): 5313-5322. DOI: https://doi. org/10.1021/jf0603811

Motallebi P., Niknam V., Ebrahimzadeh H., Tahmasebi Enferadi S., Hashemi M. 2015. The effect of methyl jasmonate on enzyme activities in wheat genotypes infected by the crown and root rot pathogen Fusarium culmorum. Acta Physiologiae Plantarum 37 (11): 237. DOI: https://doi.org/10.1007/ s11738-015-1988-3

Mpofu A., Sapirstein H.D., Beta T. 2006. Genotype and environmental variation in phenolic content, phenolic acid composition, and antioxidant activity of hard spring wheat. Journal of Agricultural and Food Chemistry 54 (4): 1265-1270. DOI: https://doi.org/10.1021/jf052683d

Mur L.A., Mandon J., Persijn S., Cristescu S.M., Moshkov I.E., Novikova G.V., Hall M.A., Harren F.J., Hebelstrup K.H., Gupta K.J. 2013. Nitric oxide in plants: an assessment of the current state of knowledge. AoB Plants 5 (0): pls052. DOI: https://doi.org/10.1093/aobpla/pls052

Murphy M.E., Noack E. 1994. Nitric oxide assay using hemoglobin method. Methods in Enzymology 233: 240-250. DOI: https://doi.org/10.1016/s0076-6879(94)33027-1

Nicaise V., Roux M., Zipfel C. 2009. Recent advances in PAMPtriggered immunity against bacteria: pattern recognition receptors watch over and raise the alarm. Plant Physiology 150 (4): 1638-1647. DOI: https://doi.org/10.1104/ pp.109.139709

Nielsen L.K., Jensen J.D., Nielsen G.C., Jensen J.E., Spliid N.H., Thomsen I.K., Justesen A.F., Collinge D.B., Jørgensen L.N. 2011. Fusarium head blight of cereals in Denmark: species complex and related mycotoxins. Phytopathology Journal 101 (8): 960-969. DOI: https://doi.org/10.1094/phyto-0710-0188

Noorbakhsh Z., Taheri P. 2016. Nitric oxide: a signaling molecule which activates cell wall-associated defense of tomato against Rhizoctonia solani. European Journal of Plant Pathology 144 (3): 551-568. DOI: https://doi.org/10.1007/ s10658-015-0794-5 
Paris R., Lamattina L., Casalongue C.A. 2007. Nitric oxide promotes the wound-healing response of potato leaflets. Plant Physiology and Biochemistry 45 (1): 80-86. DOI: https:// doi.org/10.1016/j.plaphy.2006.12.001

Ponts N., Couedelo L., Pinson-Gadais L., Verdal-Bonnin M.N., Barreau C., Richard-Forget F. 2009. Fusarium response to oxidative stress by $\mathrm{H}_{2} \mathrm{O}_{2}$ is trichothecene chemotypedependent. FEMS Microbiology Letters 258 (2): 102-107. DOI: https://doi.org/10.1111/j.1574-6968.2009.01521.x

Qiao M., Sun J., Liu N., Sun T., Liu G., Han S., Hou C., Wang D. 2015. Changes of nitric oxide and its relationship with $\mathrm{H}_{2} \mathrm{O}_{2}$ and $\mathrm{Ca}^{2+}$ in defense interactions between wheat and $\mathrm{Puc}-$ cinia triticina. PLoS ONE 10 (7): e0132265. DOI: https:// doi.org/10.1371/journal.pone.0132265

Ribichich K.F., Lopez S.E., Vegetti A.C. 2000. Histopathological spikelet changes produced by Fusarium graminearum in susceptible and resistant wheat cultivars. Plant Disease Journal 84 (7): 794-802. DOI: https://doi.org/10.1094/ pdis.2000.84.7.794

Ruan Y., Comeau A., Langevin F., Hucl P., Clarke J.M., BruleBabel A., Pozniak C.J. 2012. Identification of novel QTL for resistance to Fusarium head blight in a tetraploid wheat population. Genome 55 (12): 853-864. DOI: https://doi. org/10.1139/gen-2012-0110

Schneider C., Boeglin W.E., Yin H., Porter N.A., Brash A.R. 2008. Intermolecular peroxyl radical reactions during autoxidation of hydroxy and hydroperoxy arachidonic acids generate a novel series of epoxidized products. Chemical Research in Toxicology 21 (4): 895-903. DOI: https://doi. org/10.1021/tx700357u

Shetty N.P., Jørgensen H.J.L., Jensen J.D., Collinge D.B., Shetty H.S. 2008. Roles of reactive oxygen species in interactions between plants and pathogens. European Journal of Plant Pathology 121: 267-280. DOI: 10.1007/s10658-008-9302-5

Shin S., Kim K.H., Kang C.S., Cho K.M., Park C.S., Okagaki R., Park J.C. 2014. A simple method for the assessment of fusarium head blight resistance in Korean wheat seedlings inoculated with Fusarium graminearum. The Plant Pathology Journal 30 (1): 25-32. DOI: https://doi.org/10.5423/ppj. oa.06.2013.0059

Singh S., Gupta A.K., Kaur N. 2012. Differential responses of antioxidative defence system to long-term field drought in wheat (Triticum aestivum L.) genotypes differing in drought tolerance. Journal of Agronomy and Crop Science 198 (3): 185-195. DOI: https://doi.org/10.1111/j.1439-037x.2011.00497.x

Sorahinobar M., Niknam V., Ebrahimzadeh H., Soltanloo H., Behmanesh M., Tahmasebi Enferadi S. 2015. Central role of salicylic acid in resistance of wheat against Fusarium graminearum. Journal of Plant Growth Regulation 35 (2): 477-491. DOI: https://doi.org/10.1007/s00344-015-9554-1

Sorahinobar M., Niknam V., Ebrahimzadeh H., Soltanloo H., Moradi B., Bahram M. 2016. Lack of association between Fusarium graminearum resistance in spike and crude extract tolerance in seedling of wheat. European Journal of Plant Pathology 144 (3): 525-538. DOI: https://doi.org/10.1007/ s10658-015-0792-7

Taheri P., Irannejad A., Goldani M., Tarighi S. 2014. Oxidative burst and enzymatic antioxidant systems in rice plants during interaction with Alternaria alternate. European Journal of Plant Pathology 140 (4): 829-839. DOI: https://doi. org/10.1007/s10658-014-0512-8

Tatar O., Gevrek M.N. 2008. Influence of water stress on proline accumulation, lipid peroxidation and water content of wheat. Asian Journal of Plant Sciences 7 (4): 409-412. DOI: https://doi.org/10.3923/ajps.2008.409.412

Tian Y., Tan Y., Liu N., Liao Y., Sun C., Wang S., Wu A. 2016. Functional agents to biologically control deoxynivalenol contamination in cereal grains. Frontiers in Microbiology 7: 395. DOI: https://doi.org/10.3389/fmicb.2016.00395

Tortora M.L., Díaz-Ricci J.C., Pedraza R.O. 2012. Protection of strawberry plants (Fragaria ananassa Duch.) against anthracnose disease induced by Azospirillum brasilense. Plant and Soil 356 (1-2): 279-290. DOI: https://doi.org/10.1007/ s11104-011-0916-6

Underwood W. 2012. The plant cell wall: a dynamic barrier against pathogen invasion. Frontiers in Plant Science 3: 85. DOI: https://doi.org/10.3389/fpls.2012.00085

Voigt C. 2014. Callose-mediated resistance to pathogenic intruders in plant defense related papillae. Frontiers in Plant Science 5: 168. DOI: https://doi.org/10.3389/fpls.2014.00168

Wang X., Cai J., Liu F., Dai T., Cao W., Wollenweber B., Jiang D. 2014. Multiple heat priming enhances thermo-tolerance to a later high temperature stress via improving subcellular antioxidant activities in wheat seedlings. Plant Physiology and Biochemistry 74: 185-192. DOI: https://doi. org/10.1016/j.plaphy.2013.11.014

Yang F., Svensson B., Finnie C. 2011. Response of germinating barley seeds to Fusarium graminearum: The first molecular insight into Fusarium seedling blight. Plant Physiology and Biochemistry 49 (11): 1362-1368. DOI: https://doi. org/10.1016/j.plaphy.2011.07.004

Yi S.Y., Shirasu K., Moon J.S., Lee S.G., Kwon S.Y. 2014. The activated SA and JA signaling pathways have an influence on flg22-triggered oxidative burst and callose deposition. PLoS ONE 9 (2): e88951. DOI: https://doi.org/10.1371/journal. pone. 0088951

Yoshida M., Kawada N., Nakajima T. 2007. Effect of infection timing on Fusarium head blight and mycotoxin accumulation in open and closed-flowering barley. Phytopathology 97 (9): 1054-1062. DOI: https://doi.org/10.1094/phyto-979-1054

Zaninotto F., La Camera S., Polverari A., Delledonne M. 2006. Cross talk between reactive nitrogen and oxygen species during the hypersensitive disease resistance response. Plant Physiology 141 (2): 379-383. DOI: https://doi.org/10.1104/ pp.106.078857

Zhang X., Fu J., Hiromasa Y., Pan H., Bai G. 2013b. Differentially expressed proteins associated with fusarium head blight resistance in wheat. PLoS ONE 8 (12): e82079. DOI: https:// doi.org/10.1371/journal.pone.0082079

Zhang S., Yang X., Sun M., Sun F., Deng S., Dong H. 2009. Riboflavin-induced priming for pathogen defense in Arabidopsis thaliana. Journal of Integrative Plant Biology 51 (2): 167-174. DOI: https://doi.org/10.1111/j.1744-7909 .2008.00763.x

Zhang P., Zhou M.P., Zhang X., Huo Y., Ma H.X. 2013a. Change of defensive-related enzyme in wheat crown rot seedlings infected by Fusarium graminearum. Cereal Research Communications 41 (3): 431-439. DOI: https://doi.org/10.1556/ crc.2013.0014

Zhou K., Hao J., Griffey C., Chung H., O’Keefe S.F., Chen J., Hogan S. 2007. Antioxidant properties of fusarium head blightresistant and -susceptible soft red winter wheat grains grown in Virginia. Journal of Agricultural and Food Chemistry 55 (9): 3729-3736. DOI: https://doi.org/10.1021/jf070147a

Zhou W.C., Kolb F.L., Riechers D.E. 2005. Identification of proteins induced or upregulated by Fusarium head blight infection in the spikes of hexaploid wheat (Triticum aestivum). Genome 48 (5): 770-780. DOI: https://doi.org/10.1139/g05-041

Zhu Z., Xu F., Zhang Y., Chengc Y.T., Wiermer M., Li X., Zhang Y. 2010. Arabidopsis resistance protein SNC1 activates immune responses through association with a transcriptional corepressor. Proceedings of the National Academy of Sciences of the United States of America 107 (31): 1396013965. DOI: https://doi.org/10.1073/pnas.1002828107 